median longitudinal cinereous stripe, spreading out on hind border of third segment and covering fourth. No discal macrochaetae. Legs long, yellowish, tarsi black. Front tarsi considerably longer than front tibiae, but not nearly twice as long. Other tarsi but little shorter than front tarsi. Wings clear, third vein with three or four bristles at extreme base. Tegulae saturate tawny, halteres yellow-white. Apical cell very narrowly open, ending but little before actual tip of wing.

\title{
A SOUTHERN RACE OF DATANA PERSPICUA GR. AND ROB. (VAR. MESILLAE).
}

BY T. D. A. COCKERELL, MESIllA, NEW MEXICO.

On July 20, I896, Mr. Sherfey, our superintendent of schools, brought me great numbers of a larva on Rhus canaaensis (aromatica), which he had found in his garden in Mesilla, New Mexico. I was surprised to see that they belonged to Datana - a genus I had never before seen or heard of in New Mexico. On comparing them with the descriptions in Dr. Packard's recent magnificent monograph, I felt sure, from the concolorous hairs and other characters, that I had before me a variety of ministra, similar to, but not identical with, the var. californicd (Riley). The larvae were $35 \mathrm{~mm}$. long, and differed from the description of ministra by the dark reddish prothoracic shield; the base of the legs was dull crimson; head black; lines on body sulphur yellow.

On July 22, Mr. Sherfey brought me eggs and young larvae from the same bush, showing some irregularity in the broods. The eggs were laid in great numbers, touching, on the under side of the leaf; they were chalk-white, rounded, rather low, hardly shiny, not perceptibly sculptured, with the usual black speck. The young larvae were dark crimson with chrome yellow lines and black heads.

$\mathrm{Mr}$. Sherfey kindly undertook to raise the moths for me, and they emerged in numbers at the middle of August. To my surprise, the moths were evidently not ministra, but belonged with perspicua and robusta. Dr. H. G. Dyar, to whom I sent specimens, assures me that they are perspicua, slightly tending in the direction of robusta, but still unmistakable perspicua. A comparison with Dr. Packard's figures entirely supports this view, but the oblique streak to the apex of the primaries is almost or quite obsolete.

$D$. perspicua is a northern species, which does not appear to give off any southern segregates in the eastern U. S.; but in the Central Region we had already a very distinct offshoot, the $D$. robusta Strecker, 1872 , found in the Lower Sonoran zone in Texas. Mesilla, as Prof. Townsend and the writer have shown elsewhere, is in the Upper Sonoran, and it is therefore not surprising that the representative of $D$. perspicua should be different from robusta, and more closely approximate to the type. That the modification is more marked in the larva than in the imago is interesting, but not surprising, considering that the moths are nocturnal, while the larvae are exposed in broad daylight, and doubtless possess warning colors.

It appears that $D$. perspicua has been taken by Prof. Gillette at light. In Mesilla, when the moths must have been emerging in great numbers, I never took any at light.

For this Mesilla race of $D$ perspicua, I will propose the varietal name mesillae. 

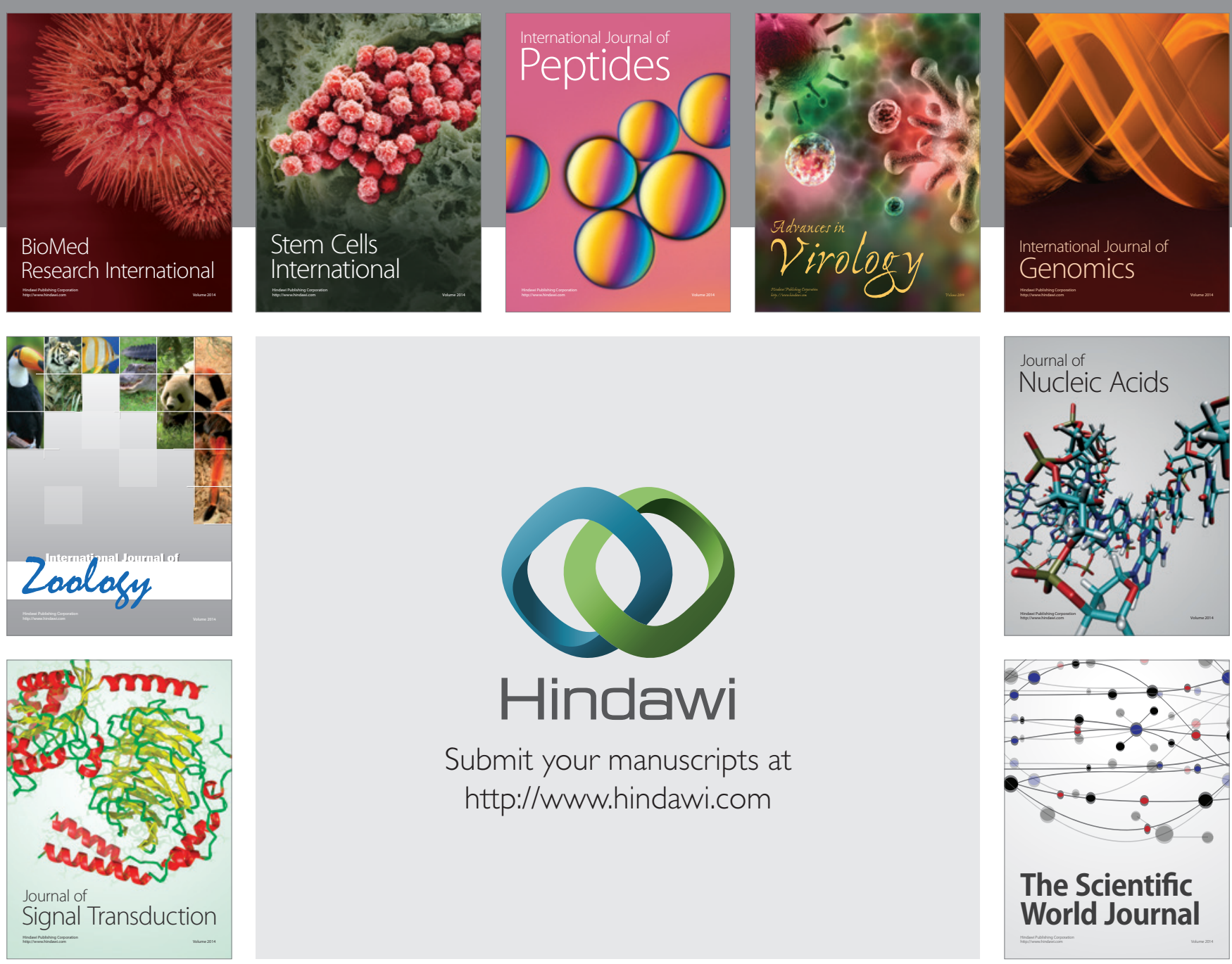

Submit your manuscripts at

http://www.hindawi.com
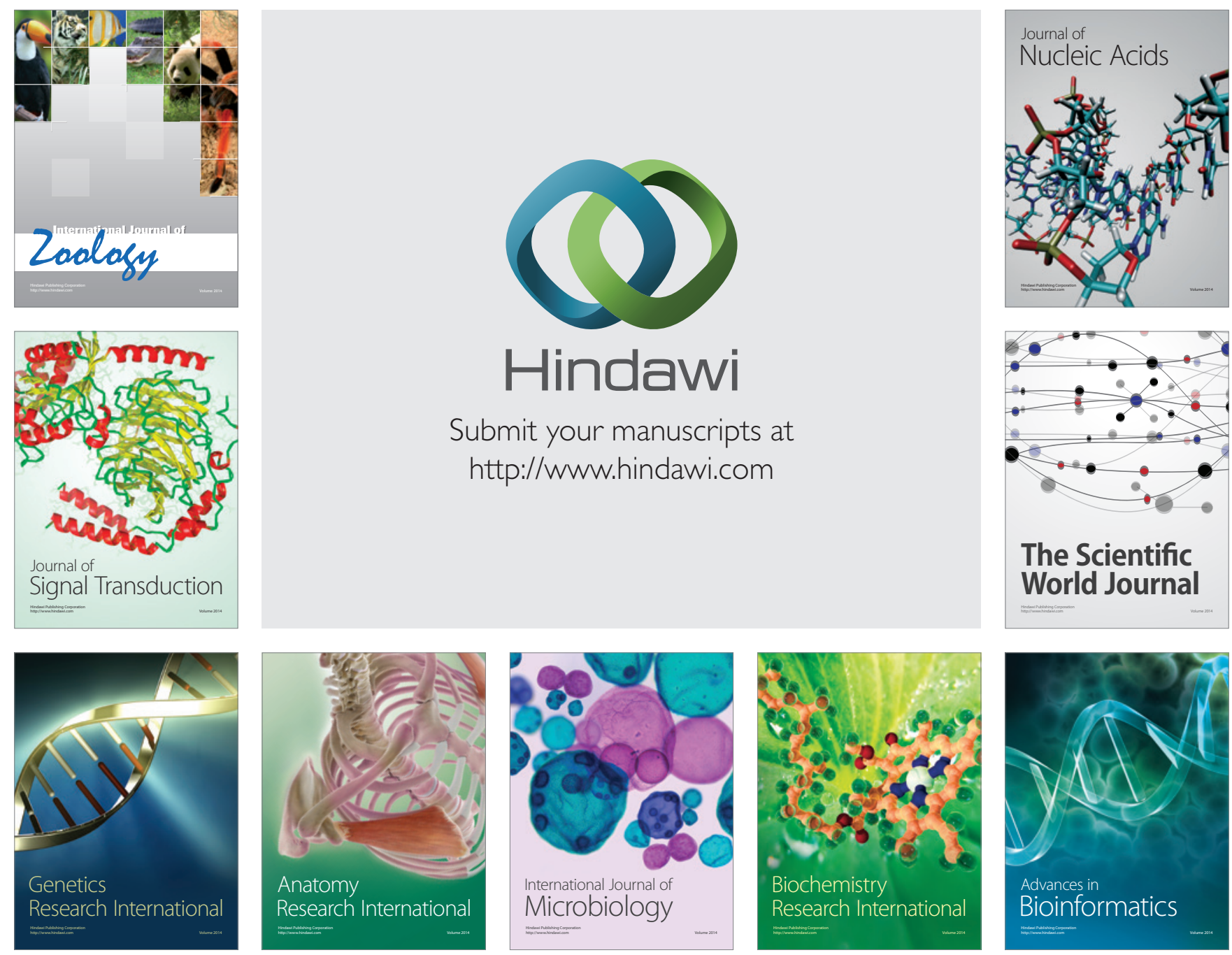

The Scientific World Journal
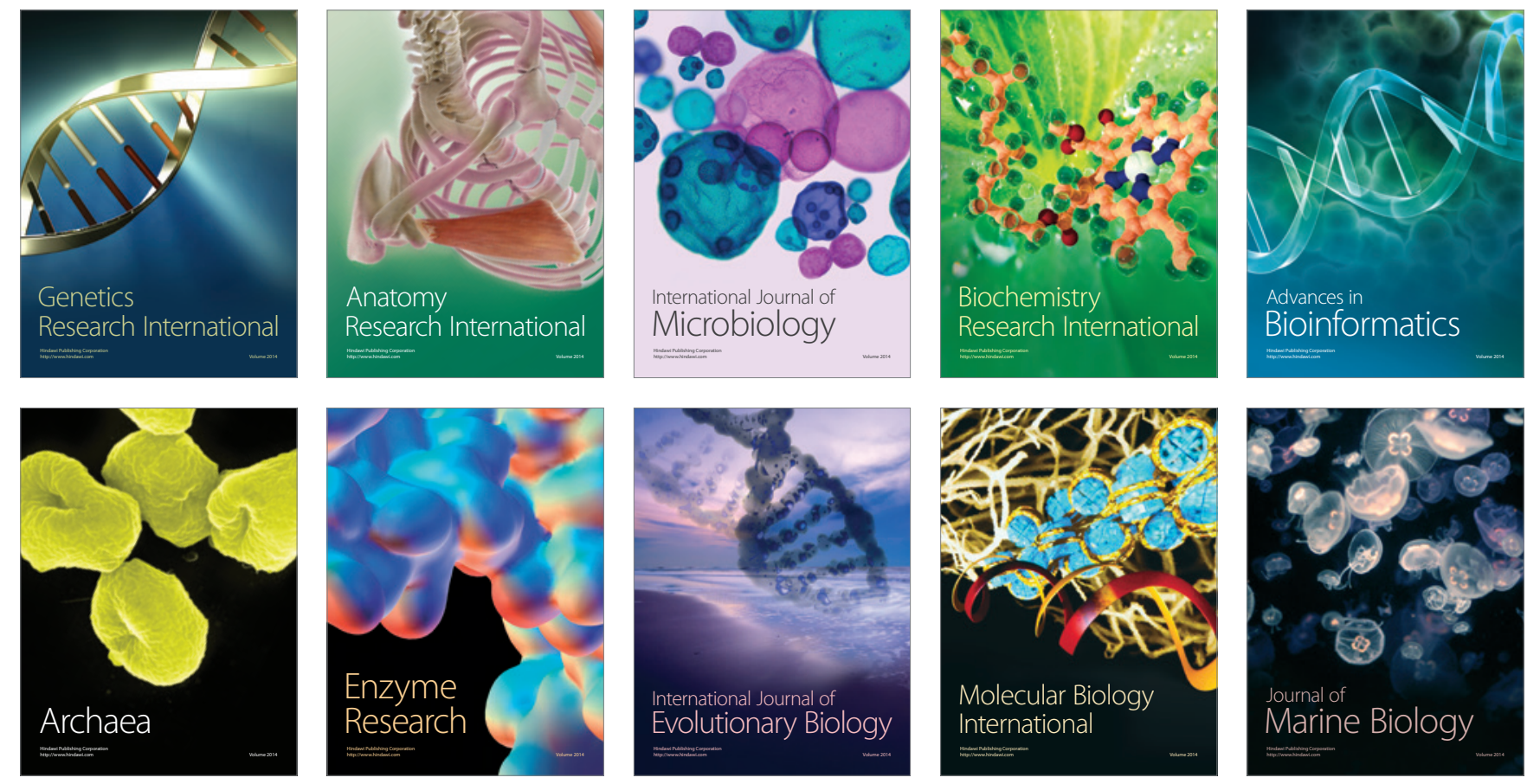